\title{
Refik Saydam: A Pioneer in the Fight Against Infectious Diseases
}

\author{
Cem Hakan Başaran (iD \\ Department of History of Medicine and Ethics, Eskişehir Osmangazi University School of Medicine, Eskişehir, Turkey
}

$\mathrm{R}$ efik Saydam (1881-1942), MD, who served as the Minister of Health for 15 years in the early period of the republic, is a well-known physician and politician who is being remembered during the current pandemic, especially in terms of fighting against epidemics and implementing preventive healthcare policies. Saydam played a significant role in the progressive steps taken by the Republic of Turkey in healthcare, implementation of healthcare policies and foundation of new institutions.

İbrahim Refik Saydam completed his primary and secondary education in Istanbul, entered Çengelköy Medical High School (Çengelköy Tibbiye İdadisi) in 1896 and graduated from Military Medical School (Askeri Tibbiye) as a captain in 1905. After one year of compulsory internship at Gülhane Clinic Hospital (Gülhane Seririyat Hastanesi), he worked as an assistant doctor for one more year in the histology and embryology department of the hospital. After working at the 3rd Army Central Hospital and Manastır Hospital between April 1908 and May 1909, Saydam was assigned to Maltepe Military Hospital and Feshane. While working there, he won a competition and went to Germany for education with a state scholarship. He attended classes at the Berlin Military Medical Academy, Charité Clinic and German military units for two years from August 1910. He returned to the country in 1912 with the outbreak of the Balkan War. Refik Saydam, who served in various military units between 1912-1914, mainly struggled with infectious diseases, especially cholera. During the First World War (1914-1918), he served as the Assistant General Inspector of the Field Sanitary and remained in this position until the Armistice of Mudros was signed on October 30, 1918 (1).

Refik Saydam landed in Samsun on May 19, 1919, in the entourage of Mustafa Kemal Pasha (Atatürk) as the Deputy of Medical Inspector (Sihhiye Müfettiş Yardımcısı). From this date on, together with Mustafa Kemal Pasha, he went from Samsun to Havza, Amasya, Sivas and Erzurum and participated in the Erzurum and Sivas Congresses. After Mus-
Corresponding Author: Cem Hakan Başaran

E-mail:

cemhakanbasaran@gmail.com

Received: December 2, 2021 Accepted: December 28, 2021 Published: December 30, 2021

Suggested citation: Başaran CH. Refik Saydam: A pioneer in the fight against infectious diseases. Infect Dis Clin Microbiol 2021; 3: 173-176.

DOI: $10.36519 / \mathrm{idcm} .2021 .109$ 


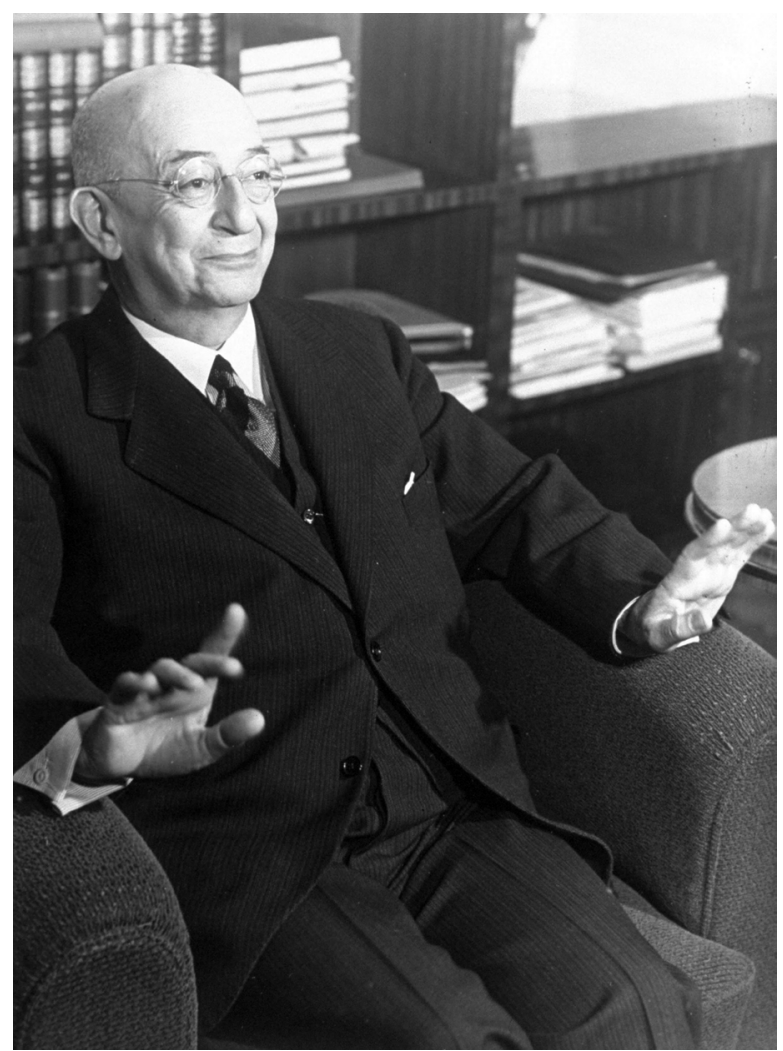

Figure Refik Saydam, 1940s. Photographer: Margaret BourkeWhite, LIFE Photo Collection.

tafa Kemal Pasha resigned from military service on the night of 8/9 July 1919, after the Inspectorate Headquarters was abolished, he was appointed as the Chief of the Infectious Diseases Service of Erzurum Hospital on September 10, 1919. However, he did not accept this duty and resigned from the military like his other friends. Saydam, who came to Ankara on December 27, 1919, with Mustafa Kemal Pasha, became one of the 115 Members of the Grand National Assembly of Turkey, opening on April 23, 1920. He represented Bayezid as a member of parliament in the Grand National Assembly of Turkey, and during this time (May 1920), he was appointed as the Head of the Health Department of the Ministry of National Defense (Millî Müdafaa Vekaleti Sihhiye Dairesi). Saydam, who resigned from his duty on September 8, 1920, became the Minister of Health on March 10, 1921(2).

Refik Saydam served as the Minister of Health for 15 years, four times at intervals between 1921-1925 and from 1925 to 1937 without interruption. In order to reorganize health services during the years of national struggle, the Ankara Government established the Ministry of Health in 1920. The administrative units in Istanbul moved to the new capital from the end of 1922, after the abolition of the sultanate. A more fundamental structuring started after 1925 when Refik Saydam became the Minister of Health again. The public health policies and practices of the early Republican period were shaped, and the health bureaucracy was permanently organized on a national scale during the period of Saydam's ministry until 1937. Refik Saydam put into practice and managed the processes of training human resources, developing the health organization and preparing the legal infrastructure for communicable diseases which threatened public health, such as malaria, syphilis, trachoma, tuberculosis, leprosy, and cholera, diphtheria, typhoid fever, smallpox (3). Saydam, who ensured the implementation of the health policies of the republican period by giving shape and direction, listed the work program on March 4, 1925, as follows. (2) In retrospect, one can see that Saydam accomplished most of the reforms he identified and aimed for:

1. Establishing a public health organization.

2. Training many physicians (before this program, a Boarding Medical Student Dormitory [Leyli Tip Talebe Yurdu] was opened in Istanbul in 1924 to create opportunities for hardworking and poor students. It succeeded in enacting the Law on the Establishment of a Faculty of Medicine in Ankara [Ankara'da Bir Tip Fakültesi Tesisi Hakkinda Kanun], but the project was put aside until 1945 due to World War II.)

3. Opening model hospitals (Model hospitals launched in Ankara, Diyarbakır, Erzurum and Sivas in 1924 and Haydarpaşa Model Hospital [Haydarpaşa Numune Hastanesi] was opened in 1936.)

4. Training midwives and health officials (Health Vocational Schools in Istanbul and Sivas and Midwife Student Dormitory within Istanbul Şişli Children's Hospital were opened in 1924, Kızılay Private Nursing School in 1925, Balıkesir Village Midwifery School etc. in 1937.) 
5. Opening maternity hospitals and nursery centers (Maternity Hospitals and Nursery Centers were opened in Ankara and Konya in 1925, Adana, Çorum, Erzurum, Kars and Malatya in 1929, Balıkesir in 1931, and Van in 1933.)

6. Opening Tuberculosis sanatoriums (Heybeliada Sanatorium was launched in 1924, Erenköy Sanatorium in 1932, Validebağ Prevantorium and Sanatorium in 1927, Yakaclk Sanatorium in 1936, and Tuberculosis Dispensaries in many cities.)

7. Fighting against malaria, syphilis, trachoma and other social diseases (A few examples of institutions from numerous studies in this field: Rabies Treatment Institutions [Kuduz Tedavi Müesseseleri] were opened in Erzurum and Sivas in 1925, Diyarbakır in 1926, Konya in 1927, and İzmir in 1930.)

8. Founding the Health and Social Assistance Units to the villages (5-10 bed examination and treatment houses [Muayene ve Tedavi Evleri] were launched in 150 district centers in 1924, in 20 district centers in 1930 and Village Group Health Offices [Köy Grup Sağlık Memurlukları] were founded.)

9. Introducing health and social laws (51 laws and 18 statutes were passed during Saydam's ministry. The most important ones were the The Law on Practice of Medicine and Medical Sciences [Tababet ve Şuabatı San'atlarının Tarzı İcrasina Dair Kanun], Public Health Law [Umumi Hifzissihha Kanunu], the Ministry of Health and Welfare's Organization and Civil Servants Law [SSYB Teşkilat ve Memurin Kanunu], etc.)

10. Establishing the Central Public Health Institution and the School of Public Health (Public Health Institution [Hifzissıhha Müessesesi] was established in 1928 and included four branches: chemistry, bacteriology, immunobiology and pharmacodynamics. The School of Public Health [Hifzissihha Okulu] was opened in 1936).

One of the most important steps taken by Refik Saydam in fighting against infectious diseases was the establishment of the Central Public Health Institution (Merkez Hifzıssihha Müessesesi). The institution had the tasks such as implementing modern public health methods, producing vaccines, sera and drugs, performing necessary laboratory tests and coordinating infrastructure centers. In this period, serious success was achieved in infectious diseases, with interventions such as the Ministry of Health's provincial organizations, the establishment of mobile teams, and free drug distribution to fight against malaria, syphilis, trachoma, and tuberculosis (3). After the death of Refik Saydam, between 1931 and 1950, BCG, in particular, typhus, smallpox, whooping cough, influenza vaccines, rabies vaccines and serum and scorpion serum were produced within the institution, which has been known as the Refik Saydam Central Public Health Institute (Refik Saydam Merkez Hifzıssihha Enstitüsü) since 1942 in memory of his name $(4,5)$. Some of these vaccines, especially the cholera vaccine, were sent to countries in need upon request. In 1938, 1 million doses of cholera vaccine were donated to China, which was trying to cope with a serious cholera epidemic (6), and tetanus and diphtheria serums were sent to countries such as Greece, Syria, and Iraq (2). In 1950, the Influenza Laboratory was recognized by the World Health Organization as the International Regional Influenza Center, and influenza vaccine production was started. The other importance of the institution was its studies in the field of statistics and methodology on the management of public health and infectious diseases, such as data collection, reviewing, analysis techniques, mapping studies. Refik Saydam Public Health Institute started to lose power for various reasons in the following years, and the institution was closed in 2011. A new ministry institution was established under the name of the Public Health Institution of Turkey (Türkiye Halk Sağlığı Kurumu), and some duties were distributed within this new institution (3). During the pandemic period in Turkey, the name of the Refik Saydam Health Institute was frequently mentioned in terms of epidemic policies and epidemic management, and the need for such an institution was emphasized for many times.

When Saydam took office as the first health minister of the republic, the society was devastated by infectious diseases such as smallpox, typhus, cholera, 
relapsing fever, syphilis, tuberculosis, malaria and trachoma, and there were not enough staff to fight. Fighting against infectious diseases was one of the main issues that Refik Saydam spent the most effort on. In order to increase the participation of the physicians in this struggle and determine a common roadmap, National Turkish Medical Congresses were organized beginning from 1925. With these congresses, the geographical distributions of infectious diseases such as malaria, trachoma, tuberculosis and syphilis were determined, and the decisions taken at the congress affected government policies (7). Saydam also encouraged publishing in the field of health, again began to publish Sihhiye Mecmuası (a journal, then renamed as Sağlık Dergisi since 1945) and gave moral and material support to the publication of the Journal of Hastahane (1924-1930), which was published in Ankara (8).

Refik Saydam was the General President of the Red Crescent Society (Kizllay Cemiyeti) for 14 years from 1925 and made significant contributions to the development of the Red Crescent (2). Saydam, who served as the Minister of Interior and CHP General Secretary for a short time in the cabinet established after Atatürk's death, was appointed as Prime Minister by President İsmet İnönü on January 25, 1939. During this period, he focused on solving Turkey's internal and external problems due to the Second World War. Refik Saydam died of a heart attack at midnight in the Pera Palas Hotel, where he stayed during his study trip to Istanbul on July 8, 1942 (2). Refik Saydam, who determined and institutionalized the health policies of the republican period with his hard work and dedication to the field of health, never married and a year before he died, he donated a mansion in İstanbul which was his entire wealth to Darüşşafaka Society (Darüşşafaka Cemiyeti), and his house in Ankara to Red Crescent (9).

This is unfortunate that Refik Saydam the most significant name and the founder of the health system in modern Turkey didn't publish his memories. His political life and works in the field of health can be read as the story of the young Republic of Turkey.
Ethical Approval: N.A.

Informed Consent: N.A.

Peer-review: Externally peer-reviewed
Conflict of Interest: The author declares no conflict of interest..

Financial Disclosure: The author declared that this study has received no financial support.

\section{REFERENCES}

1 Dr. Refik Saydam'ın tercüme-i hali [Internet]. TBMM Arşivi. (cited November 29, 2021) Available from: https://www.tbmm. gov.tr/eyayin/GAZETELER/WEB/MAZBATALAR/TBMM/d03/ HT_46_1_3.pdf

2 Dr. Refik Saydam 1881-1942 Ölümünün 40. Yllı Anısına. Ankara: Sağlık ve Sosyal Yardım Bakanlığı-Sağlık Propagandası ve Tibbi İstatistik Genel Müdürlüğü; 1982:7-59.

3 Artvinli F. Türkiye'de Salgın Yönetimi: Kurumsallaşma ve Kurumsal Hafıza Sorunu [Internet]. İstanbul: İstanbul Politik Araştırmalar Enstitüsü; 2020. (December 12, 2020; cited November 29, 2021) Available from: https://www.istanpol.org/ post/t\%C3\%BCrkiye-de-salg\%C4\%B1n-y\%C3\%B6netimi-kurumsalla\%C5\%9Fma-ve-kurumsal-haf\%C4\%B1za-sorunu

4 Metintaş MY. Refik Sağlam'ın yaşamı ve kişiliği [PhD thesis]. Ankara Üniversitesi Sosyal Bilimler Enstitüsü; 2008.
5 Sağlık Hizmetlerinde 50 Yll. Ankara: Sağlık ve Sosyal Yardım Bakanlığı Yayınları; 1973.

6 Giray F. 1938 Çin kolera salgınında Türkiye'den gönderilen aşılar ve Çin basınındaki yansımalan. Toplumsal Tarih. 2020;318:50-2.

7 Arlkan A. Milli Türk Tip Kongreleri (1923-1968) ve Türkiye Sağllk Politikalarnna Etkileri. İstanbul: Türkiye Tip Akademisi; 2010.

8 Başaran CH, Poyraz Demirsoy N. Operatör Doktor Ömer Vasfi Aybar ve Ankara'da yayımladığı Türk Hekimi Dergisi. Osmanlı Bilimi Araştırmaları. 2020;21(1):71-100. [CrossRef]

9 İbrahim Refik Saydam (1881-1942) [Internet]. Atatürk Ansiklopedisi. (cited November 29, 2021). Available from: https://ataturkansiklopedisi.gov.tr/bilgi/ibrahim/ 